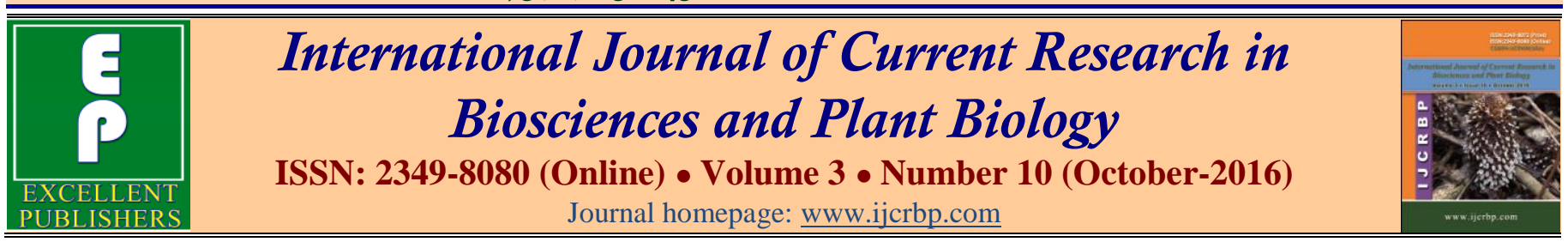

\title{
Assessment of Performance of Four Cucumber (Cucumis sativus L.) Cultivars in Iwollo, South-Eastern Nigeria
}

\author{
${ }^{1}$ Department of Horticultural Technology, Enugu State Polytechnic, Iwollo, Enugu State, Nigeria \\ ${ }^{2}$ Department of General Studies, Enugu State Polytechnic, Iwollo, Enugu State, Nigeria \\ 3 Department of Agricultural Technology, Enugu State Polytechnic, Iwollo, Enugu State, Nigeria \\ ${ }^{4}$ Department of Computer Science, Enugu State Polytechnic, Iwollo, Enugu State, Nigeria
}

J. O. Adinde ${ }^{*}$, U. J. Anieke ${ }^{2}$, O. J. Uche ${ }^{3}$, A. C. Aniakor3, L. C. Isani ${ }^{4}$ and A. A. Nwagboso ${ }^{2}$

*Corresponding author.

\begin{abstract}
A bstract
Field assessment of performance of four cucumber (Cucumis sativus L.) cultivars namely, Ashely, Marketer, Super-marketer and Pointsett-76 in Iwollo, South-eastern, Nigeria was carried out at the Teaching and Research farm of the Department of Horticultural Technology, Enugu State Polytechnic, Iwollo. The four cultivars made up the treatments. The experiment was laid out in Randomized Complete Block Design (RCBD) with four replications. Data on days to $50 \%$ emergence, emergence percentage, vine length, number of leaves per plant, number of branches per plant, leaf area index, days to first female flower initiation, number of fruits per plant, weight of a fresh fruit, fresh fruit weight per plant and fresh fruit yield per hectare were collected and analysed using Analysis of variance (ANOVA) for Randomized Complete Block Design (RCBD). The treatment means were separated using least significant difference at 5\% probability level. The results showed that there were significant differences $(p<0.05)$ among the cultivars at 45 days after planting in vine length, number of leaves per plant, number of branches per plant and leaf area index with Pointsett-76 having superior values. Pointsett-76 cultivar was also significantly $(p<0.05)$ superior to other cultivars as regard to days to first female flower initiation, number of fruits per plant, weight of a fresh fruit, fresh fruit weight per plant and in fresh fruit yield per hectare. Pointsett-76 cultivar therefore performed better than the other three varieties in the study area and could be recommended to farmers for improved production of cucumber.
\end{abstract}

\section{Article Info}

Accepted: 26 September 2016

Available Online: 06 October 2016

\section{Keywords}

Cucumber cultivars

Cucumis sativus

Emergence

Flower initiation

\section{Introduction}

Cucumber (Cucumis sativus L.) is a member of the Cucurbitaceae family which is comprised of 118 genera and 825 species. Members of this family are spread mainly in tropical and subtropical regions of the world (Wang et al., 2007). According FAO (2006), the most important cucurbits in terms of world total production are water melon (Citrullus lanatus L.), cucumber (Cucumis sativus L.) and melon (Cucumis melon L.). Cucumber originated in India and became popular throughout the Egyptian and the Greek-Roman Empire (Renner et al., 2007). It is an important vegetable crop grown in the temperate and tropical zones of the world. With respect to economic importance, cucumber ranks fourth after tomatoes, cabbage and onion in Asia 
(Tatlioglu, 1993; Eifediyi and Remison, 2010), and second after tomato in Western Europe (Phu, 1997). Soft and succulent, the vegetable crop is cherished by man and eaten in salads or sliced into stew in tropical regions. Its juice is often recommended as source of silicon to improve the health and complexion of the skin (Duke, 1997). Cucumber is a very good source of vitamins A, C, $\mathrm{K}$, B6, potassium, pantothenic acid, magnesium, phosphorus, copper and manganese, fibre, and antioxidants (Vimala et al., 1999). It helps in healing diseases of urinary bladder and kidney; digestive problems like heartburn, acidity, gastritis and ulcer (Garcia-Closes et al., 2004). The ascorbic acid and caffeic acid contained in cucumber help to reduce skin irritation and swollen (Okonmah, 2011). It requires a stable warm temperature for good yield (Cobeil and Gosselin, 1990). It develops rapidly, with a shorter time from planting to harvest than for most crops (Wehner and Guner, 2004). It is an all year round out door vegetable in the tropic and an important greenhouse vegetable especially in Northern Europe and North America (Mingboa, 1991). Phu (1997) stated that cucumber could be cultivated in the field during the summer and winter in greenhouses using artificial heating.

There exist three main varieties of cucumber; slicing, plickling and burpless. Within these varieties, several different cultivars have emerged. Many cultivars of cucumber exist with varying shapes, skin colours and carotene content (Simon, 1992). Some cucumber cultivars available in Nigeria are Ashley, Royal F1, Pointsett-76, Centriolo Marketer, Marketmoore, Supermarketer, Beit-alpha etc. Cucumber cultivars have distinctive characteristics/ traits which make them suitable for a particular environment or condition in terms of tolerances to drought, disease resistance, early maturing and yield. The variation in performance of cucumber cultivars has been widely documented by many scholars (Mingboa, 1991; Manyvong, 1997; Sharma et al., 2000; Odeleye and Odeleye, 2001; Hamid et al. 2002; Maqsood et al., 2004; Ojeifo et al., 2008) which could be as a result of environmental factors and genetic composition.

Production of cucumber in Nigeria is mostly done in the northern part of the country. There was a general belief that cucumber can only be grown in the north. However, cucumber cultivation in the south-eastern Nigeria has been found to be achievable under moderate rainfall (Enujeke, 2013a). The crop is now been cultivated in some parts of south-eastern Nigeria however; the area under cucumber production and the yield per unit area are low. Farmers in south-eastern Nigeria are often been discouraged from embarking on commercial cucumber production due to high incidence of pests and diseases due to extreme temperature, heavy rainfall and high humid condition obtainable in the South which do not favour cucumber production. Other factors that cause low cucumber yield in the zone are lack of appropriate cultural practices (Ekwu, et al., 2007) and non accessibility of varieties well suited for its agro-climatic condition. Iken and Anusa (2004) reported that because of the differences in yield potential of different ecological zones, testing of new crop varieties across the country becomes an established practice in plant breeding. Varietal differences affect or determine the growth and yield of crops. Majanbu et al. (1996) and Sajjan et al. (2002) reported that growth characters of crops such as plant height, vine length, leaf area, member of leaves or branches, and fruit production were influenced by genetic factors of the different varieties.

Ibrahim et al, (2000) reported that the differences in growth indices of crops are normally attributed to their genetic constitution. Akinfoesoya et al. (1997) and; Odeleye and Odeleye (2001) indicated that growth characters, yield and its component differed among crop varieties. Ray and Sinclair (1997) attributed differences between the growth characters of crop genotypes to photosynthetic activity of leaves that is, internal factors and the differences in high distribution on leaf surface of the crop canopy, leaf arrangement, differences in chlorophyll content, activity photosynthetic enzymes and differences in stomatal conductance values. Costa and Campos (1990), Gardner et al. (1990) and Zaki et al. (1999) attributed yield differences in crop cultivars to stomatal conductance value and to differences between genotypes in partitioning of photosynthetic materials towards economic yield. Clark et al. (1997) reported that the genotypes differences in yield and its components may be due to variations in genetic structure, mineral concentration and potentials to transport photosynthetic materials within plants. Evaluations of different cucumber cultivars have been conducted in various countries. Shetty and Wehner (1998) studied 18 cucumber cultivars on trellis and flat beds and concluded that the best cultivars for marketable yield were Summer Top and Rusty Blight, while best overall cultivars on flat beds were Poinsett-76 and Spring-440. Resende (1999) conducted a trail on ten cultivars of cucumber and observed that Indaial, Score, Colonia and Ginga AG-77 gave the highest yield, best growth performance with longest fruits and highest commercial value. 
Sharma et al. (2000) studied the performance of various cucumber cultivars under field and greenhouse conditions and observed that the yield under field condition was higher than greenhouse conditions and cultivars Poinsett-76 and K-75 had higher yields than other cultivars, which could be attributed to greater fruit length, weight and yield per plant. Hamid et al. (2002) performed a field trail on six cucumber cultivars under agro-climatic conditions of Swat and found that cultivar PARC-1 was the best among all the cultivars studied. Ojeifo et al. (2008) also revealed that Marketmoore and Centriolo marketer were promising among all the cucumber varieties they studied in southern Nigeria.

The literature indicates that the performance of the cultivars varies depending upon the climatic conditions. Selecting high yielding and disease resistance cultivar suitable for south-east agro-climatic condition can help to increase cucumber production in the area. At present, no cultivar of cucumber has been identified to be best suitable for Iwollo area, southeastern Nigeria. The objective of the study was therefore to assess the performance of four cucumber (Cucumis sativus L.) cultivars in Iwollo, southeastern Nigeria.

\section{Materials and methods}

\section{Experimental site}

The experiment was conducted at the Teaching and Research Farm of the Department of Horticultural Technology, Enugu State Polytechnic, Iwollo. The study was carried out between June - August, 2015. The study area is located at Southeast Agro-Ecological Zone of Nigeria; co-ordinate "N6 27 " "E7 17 " (Maplandia, 2015). The rainfall pattern is bimodal; between April to June and September - November with short spell in August.

\section{Source of seeds}

Seeds of the cucumber cultivars (treatments) used were sourced from Department of Horticultural Technology, Enugu State Polytechnic, Iwollo.

\section{Soil sampling}

Prior to land preparation, soil samples were randomly collected from the experimental field from $0-20 \mathrm{~cm}$ depth and thoroughly mixed to make a composite soil sample. The composite soil sample was analyzed for soil physico-chemical properties.

\section{Experimental design}

The experiment was laid out in Randomized Complete Block Design (RCBD) with four replications. Four cultivars of cucumber (Cucumis sativus) were sown as treatments.

The treatments were:

$\begin{array}{lll}\text { T1 } & - & \text { Pointsett-76 } \\ \text { T2 } & - & \text { Marketer } \\ \text { T3 } & - & \text { Super-marketer } \\ \text { T4 } & - & \text { Ashley }\end{array}$

\section{Field operation}

The experimental field size of $13 \mathrm{~m} \times 11.5 \mathrm{~m}\left(149.5 \mathrm{~m}^{2}\right)$ (0.01495ha) was marked out using measuring tape, rope and peg. Land clearing was done using cutlass. The debris was packed using rake. The soil was tilled to fine tilth. The field was demarcated into 4 blocks each block containing 4 plots. 16 plots of $2.5 \mathrm{~m} \mathrm{x}$ $2.5 \mathrm{~m}\left(6.25 \mathrm{~m}^{2}\right)$ each was prepared using hoe. $1 \mathrm{~m}$ and $0.5 \mathrm{~m}$ alleys separated adjacent blocks and plots respectively. Poultry droppings at the rate of 15 tons/ha (dry weight) was incorporated into the soil. Four cucumber seed cultivars (treatments) were sown on the plots at 2 seeds per hill at a depth of $2.5 \mathrm{~cm}$, using spacing of $0.75 \mathrm{~m} \times 1 \mathrm{~m}$. A total of 18 seeds were sown in each plot giving a plant population of 20,000 plants per hectare. Insect pests were controlled using Knockoff (Lamda cyhalothrin) insecticide. Fungal disease was controlled using Ridomil (Metalaxyl) fungicide. Regular weeding was done every two weekly interval using hoe.

\section{Data collection}

Six middle stands from each plot were tagged and used as sample plants upon which data collection was made. Data were collected on days to $50 \%$ emergence, percentage emergence, vine length, number of leaves per plant, number of branches per plant, leaf area index, days to first female flower initiation, number of fruits per plant, weight of a fresh fruit, fresh fruit weight per plant, and fresh fruit yield per hectare.

\section{Days to 50\% emergence}

Days to $50 \%$ emergence was determined by counting the days from the date of planting to the date up to half of the sown seeds emerged. 


\section{Emergence percentage}

Data on emergence percentage was obtained 10 days after sowing by counting the number of seedlings emerged and dividing by the number of seeds sown then multiplied by 100 .

$$
\text { Emergence percentage }=\frac{\text { Total seeds emerged }}{\text { Total seeds sown }} \times 100
$$

\section{Vine length}

Vine length was measured with measuring tape from the base to the growing tip of the main vine.

\section{Number of branches per plant}

Number of branches per plant was determined by direct counting of the branches per plant.

$$
\text { No. of branches per plant }=\frac{\text { Total no. of branches on sample plants }}{\text { No. of sample plants }}
$$

\section{Number of leaves per plant}

Number of leaves per plant was determined by direct counting of the leaves per plant.

$$
\text { No. of leaves per plant }=\frac{\text { Total no. of leaves on sample plants }}{\text { No. of sample plants }}
$$

\section{Leaf area index (LAI)}

Leaf Area Index was determined using direct method as postulated by Breda (2003). This was done by measuring the leaf length and width per plant.

$$
\text { LAI }=\frac{\text { Avg. leaf length }(\mathrm{m}) \times \text { Avg. leaf width }(\mathrm{m}) \times \text { No. of leaves } \times \text { Plant density }}{\text { Area of plot }\left(\mathrm{m}^{2}\right)}
$$

\section{Days to first female flower initiation}

Days to first female flower initiation was determined by counting the days from the date of sowing to the date first female flower was seen in each plot.

\section{Number of fruits per plant}

Number of fruits per plant was determined by direct counting of the number of harvested fruits from the sample plants in each plot and dividing by the number of sample plants.
No. of fruits per plant $=\frac{\text { Total number of fruits harvested from the sample plants }}{\text { Number of sample plants }}$

\section{Weight of a fresh fruit (kg)}

Weight of a fresh fruit was determined using weighing scale to get the total weight of the harvested fruits and dividing by the number of fruits weighed.

Weight of a fresh fruit $(\mathrm{kg})=\frac{\text { Total weight of fresh fruits weighed }}{\text { Total no. of fresh fruits weighed }}$

\section{Fresh fruit weight per plant $(\mathrm{kg})$}

Fresh Fruit weight per plant was computed using the number of fruits per plant and weight of a fresh fruit.

Fruit weight per plant $(\mathrm{kg})=$ No. of fruit per plant $\times$ Weight of a fresh fruit

\section{Fresh fruit yield per hectare (ton)}

Fresh fruit yield per hectare was computed using fresh fruit weight per plant and plant density per hectare.

Fresh fruit yield per ha (ton) $=$

Fresh fruit weight per plant $\times$ Plant density $(20,000$ stands/ha).

\section{Statistical analysis}

Data collected were subjected to Analysis of Variance (ANOVA) for randomized complete block design (RCBD) using GenStat Release 10.3DE software (2011) and significant means separated using least significant difference (LSD) at 0.05 probability level as described by Obi (2002).

\section{Results}

\section{Pre-planting soil properties}

The data on the pre-planting soil physico-chemical properties of the experimental site was presented in Table 1. The particle size fracture showed that the soil was sandyloam in texture and low in fertility as reflected by the low content of organic matter $\left(17.4 \mathrm{gkg}^{-1}\right)$, and total nitrogen $\left(1.1 \mathrm{gkg}^{-1}\right)$. Soil $\mathrm{pH}$ was slightly acid with a mean value of 5.1. The available phosphorus $(\mathrm{P})\left(7.24 \mathrm{mgkg}^{-1}\right)$, potassium (K) $\left(0.21 \mathrm{cmolkg}^{-1}\right), \mathrm{Mg}\left(1.2 \mathrm{cmolkg}^{-1}\right)$ and $\mathrm{Ca}(0.9 \mathrm{cmol}$ $\mathrm{kg}^{-1}$ ) were seemingly low based on the ratings of FMANR, (1996). The low fertility status of the soil could be a true reflection of over cultivation of the soil. The slightly acidity could be as a result of precipitation with its associated erosion and leaching in the environment. 
Table 1. Pre-planting soil physico-chemical properties of the experimental site.

\begin{tabular}{ll}
\hline Parameter determined & Values obtained \\
\hline Sand & $47.6 \%$ \\
Silt & $25 \%$ \\
Clay & $27.4 \%$ \\
Textural class & Sandy-loam \\
pH $\left(\mathrm{H}_{2} \mathrm{O}\right)$ & 5.1 \\
Organic matter $(\mathrm{gkg}-1)$ & 17.4 \\
Total Nitrogen $(\mathrm{gkg}-1)$ & 1.1 \\
Available $\mathrm{P}(\mathrm{mgkg}-1)$ & 7.24 \\
Exchangeable K $(\mathrm{Cmolkg}-1)$ & 0.21 \\
CEC $(\mathrm{Cmolkg}-1)$ & 13.3 \\
Ca $(\mathrm{Cmol} / \mathrm{kg})$ & 0.9 \\
$\mathrm{Mg}(\mathrm{Cmol} / \mathrm{kg})$ & 1.2 \\
\hline
\end{tabular}

\section{Emergence parameters of four cultivars of cucumber} (Cucumis sativus)

The result of analysis of variance on emergence parameters of four cucumber cultivars as presented in Table 2 showed that there was non-significant difference $(P>0.05)$ among the treatment means. Pointsett-76, Marketer, Super-marketer and Ashley did not differ significantly in days to $50 \%$ emergence and in emergence percentage.

Table 2. Emergence parameters of four cultivars of cucumber (Cucumis sativus).

\begin{tabular}{lll}
\hline $\begin{array}{l}\text { Cucumber } \\
\text { cultivars }\end{array}$ & D50\%E & E.P(\%) \\
\hline Pointsett-76 & 8.75 & 63.89 \\
Marketer & 7.25 & 76.39 \\
Super-marketer & 7.25 & 77.78 \\
Ashley & 8.50 & 56.95 \\
$L S D_{0.05}$ & $N S$ & $N S$ \\
\hline LSD= Least significant difference; NS=Non Significant; \\
D50\% E= Days to 50 percent Emergence; EP=Emergence \\
percentage.
\end{tabular}

\section{Vegetative growth of four cucumber cultivars}

The results of the vegetative growth parameters of four cucumber cultivars evaluated were shown Table 3 . The result showed that there was non-significant difference $(p>0.05)$ among the four cucumber cultivars in vine length, number of branches per plant and number of leaves per plant at 30 days after planting. The vine length of the cucumber cultivars increased rapidly from 30 days after planting to 45 days after planting. There was significant difference $(p<0.05)$ in vine length of the cultivars investigated at 45 days after planting. Pointsett-76 cultivar had the highest vine length with a mean value of $109.00 \mathrm{~cm}$ while Super-marketer cultivar had the lowest vine length with mean value of $66.75 \mathrm{~cm}$. Marketer cultivar had the second highest mean value of $73.00 \mathrm{~cm}$ but was statistically at par with Ashley and Super-marketer. Similarly, the number of leaves per plant for the four cucumber cultivars increased rapidly from 30 days after planting to 45 days after planting. There was significant difference $(p<0.05)$ in number of leaves per plant for the cultivars evaluated at 45 days after planting. Pointsett-76 cultivar had the highest number of leaves per plant with a mean value of 61.75 , while Ashley cultivar had the lowest number of leaves per plant with a mean value of 31.5. Super-marketer cultivar attained the second highest position with a mean value of 43.00 but was statistically at par with Marketer and Ashley cultivars. Number of branches per plant differed significantly $(p<0.05)$ among the cultivars at 45 days after planting. Pointsett-76 had the highest number of branches with a mean value of 6.75 , while Marketer cultivar which had a mean value of 3.5 was the least. Super-marketer attained the second position with mean value of 5.00 but was statistically at par with Marketer and Ashley.

Consequently, there was significant difference $(p<0.05)$ in days to first female flower initiation among the cucumber cultivars studied. The highest mean days to first female flower initiation (50.75) was observed in Ashley cultivar, while the lowest (40.75 days) was observed in Pointsett-76 variety. The least mean days of 40.75 obtained in Pointsett-76 was statistically at par with 41.5 days obtained in Marketer and with 41 days obtained in Super-marketer. However, there was nonsignificant difference $(p>0.05)$ in Leaf Area Index among the four cucumber cultivars evaluated.

Table 3. Vegetative growth parameters of four cultivars of cucumber (Cucumis sativus).

\begin{tabular}{|c|c|c|c|c|c|c|c|c|}
\hline \multirow{2}{*}{$\begin{array}{l}\text { Cucumber } \\
\text { cultivars }\end{array}$} & \multicolumn{2}{|c|}{ Vine length (cm) } & \multicolumn{2}{|c|}{ No. of leaves/plant } & \multicolumn{2}{|c|}{ No. of branches/plant } & \multirow{2}{*}{ DFFF } & \multirow{2}{*}{ LAI } \\
\hline & 30DAP & 45DAP & 30DAP & 45DAP & 30DAP & 45DAP & & \\
\hline Marketer & 14.78 & $73.00^{\mathrm{b}}$ & 7.30 & $34.25^{\mathrm{b}}$ & 2.04 & $3.50^{\mathrm{b}}$ & $41.50^{\mathrm{b}}$ & 5.29 \\
\hline Ashley & 14.61 & $70.75^{\mathrm{b}}$ & 6.39 & $31.50^{\mathrm{b}}$ & 1.25 & $4.25^{\mathrm{b}}$ & $50.75^{a}$ & 4.08 \\
\hline$L S D_{0.05}$ & $N S$ & 27.7895 & $N S$ & 22.10 & $N S$ & 2.2461 & 2.7186 & $N S$ \\
\hline
\end{tabular}

$\mathrm{LSD}=$ Least significant difference; NS=Non-significant; DAP=Days after planting; DFFF= Days to first female flower; LAI= Leaf Area Index. Mean values within each column with the same alphabet are not significantly different $(p>0.05)$. 


\section{Yield of four cucumber cultivars (Cucumis sativus)}

The results of the analysis of variance on yield parameters of four cucumber cultivars studied were presented in Table 4 . There were significant differences $(p<0.05)$ in all the yield parameters evaluated. In number of fruits per plant, fresh fruit weight per plant and fresh fruit yield per hectare, Pointsett-76 cultivar had the highest mean values of $5.525,1.92 \mathrm{~kg}$ and 38.4 tons respectively, while the lowest values were obtained in
Ashley cultivar which had mean values of $2.75,0.756 \mathrm{~kg}$ and 15.13 tons respectively. Ashley cultivar was statistically at par with Marketer and Super-marketer cultivars in terms of number of fruits per plant, fresh fruit weight per plant and fresh fruit yield per plant. Similarly, Pointsett-76 had the highest mean value $(0.3475 \mathrm{~kg})$ in weight of a fresh fruit which was statistically at par with $0.32 \mathrm{~kg}$ obtained in Super-marketer. The least mean value of $0.26 \mathrm{~kg}$ obtained in Marketer was also statistically at par with $0.275 \mathrm{~kg}$ obtained in Ashley cultivar.

Table 4. Yield parameters of four cultivars of cucumber (Cucumis sativus).

\begin{tabular}{lllll}
\hline Cucumber cultivars & No. of fruits/plant & $\begin{array}{l}\text { Average fresh fruit } \\
\text { weight }(\mathbf{k g})\end{array}$ & $\begin{array}{l}\text { Fresh fruit weight/plant } \\
(\mathbf{k g})\end{array}$ & $\begin{array}{l}\text { Fresh fruit } \\
\text { yield/ha (ton) }\end{array}$ \\
\hline Pointsett-76 & $5.525^{\mathrm{a}}$ & $0.3475^{\mathrm{a}}$ & $1.92^{\mathrm{a}}$ & $38.4^{\mathrm{a}}$ \\
Marketer & $2.925^{\mathrm{b}}$ & $0.26^{\mathrm{b}}$ & $0.76^{\mathrm{b}}$ & $15.2^{\mathrm{b}}$ \\
Super-marketer & $3.525^{\mathrm{b}}$ & $0.32^{\mathrm{a}}$ & $1.13^{\mathrm{b}}$ & $22.6^{\mathrm{b}}$ \\
Ashley & $2.750^{\mathrm{b}}$ & $0.275^{\mathrm{b}}$ & $0.756^{\mathrm{b}}$ & $15.13^{\mathrm{b}}$ \\
$L S D_{0.05}$ & 1.51933 & 0.04447 & 0.5859 & 11.7181 \\
\hline
\end{tabular}

$\mathrm{LSD}=$ Least significant difference. Mean values within each column with the same alphabet are not significantly different $(p>0.05)$.

\section{Discussion}

It is evident from the results presented in Table 2 and Table 3 that there were non-significant differences in days to $50 \%$ emergence, emergence percentage and leaf area index among Poinsett-76, Marketer, Super-marketer and Ashley cultivars. Vine length, number of branches per plant and number of leaves per plant at 30DAP also did not vary significantly among the cultivars probably because the cultivars' stands were not yet fully established at that stage to express their varietal potentials. However, a perusal of Table 3 showed that Pointsett-76 cultivar had superior values at 45DAP in terms of vine length, number of branches per plant and number of leaves per plant. The significantly higher values obtained in Pointsett-76 cultivar over the other cucumber cultivars tested could be attributed to superiority in its genetic constitution with respect to vegetative growth and suitability of the cultivar to the growing conditions of the study area. The result was similar to the findings of Majanbu et al. (1996); and Ibrahim et al. (2000) who reported that genetic constitution of crop varieties influences their growth characters. Shetty and Wehner (1998) reported that Poinsett-76 and Sprint-440 performed better than other varieties in terms of vine length. Genetic nature of a cultivar enables it to adapt well to the given climatic condition. Ray and Sinclair (1997); Maqsood et al. (2004) and Enujeke (2013b and 2013c) attributed the differences between the growth characters of crop varieties to photosynthetic activities of leaves, differences in distribution of leaf surface and crop canopy, leaf arrangement, differences in chlorophyll content and activity of photosynthetic enzymes.

The superiority of Pointsett-76 cultivar in vegetative growth at 45 days after planting over Marketer, Supermarketer and Ashley cultivars was probably because it was able to effectively exhibit its good genetic make-up to exploit the newly found favourable agro-climatic conditions of the study area for rapid growth and branching. This is in harmony with the reports of Akinfoesoye et al. (1997) and Ray and Sinclair (1997) who attributed the growth characters of crop species not only to genetic constitution of the crop but also to the suitable agro-ecological zone where they can express their full genetic resources for growth and yield enhancement.

The cultivar Ashley took longer mean time (50.75 days) to produce first female flower and differed significantly with other cultivars. Pointsett-76 took shortest mean time (40.75) to produce first female flower but was statistically at par with Super-marketer and Marketer. Early female flower initiation is desirable and is an indication of early maturing.

In terms of yield, it is evident from Table 4 that Pointsett-76 cultivar produced significant higher number of fruits per plant; weight of a fresh fruit; fresh fruit 
weight per plant and fresh fruit yield per hectare compared to Marketer, Super-marketer and Ashley cultivars. These results were similar to the results of Resende (1999), who found that in case of number of fruits per plant cultivars; Indaial, Colonia, Ginga AG-77, Score and Tamor showed the best performance by producing more number of fruits per plant as compared to other cultivars evaluated. The results were also in harmony with the findings of Costa and Campos (1990); Gardner et al. (1990) and Zaki et al. (1999). The results could be compared with those of Stolk and Cools (1980), who reported that the cultivar Bright had a higher average fruit weight but the cultivar K-8499 produce many small fruits. In another trial, Sharma et al. (2000) found that the cultivars "Poinsett-76" and "K-75" gave higher yield than other cultivars. Clark et al. (1997) reported similar results and attributed the differences in yield and its components between crop genotypes to variations in genetic structure, mineral concentration and potentials to transport photosynthetic materials within plants.

Number of fruits per plant and weight of a fruit play vital role in yield per plant and the overall yield per hectare. Poinsett-76 produced the maximum number of fresh fruits per plant and the maximum weight of a fresh fruit which ideally resulted to maximum fresh fruit yield per plant and maximum fresh fruit yield per hectare. Pointsett-76 appeared to have the best genotype and environmental interaction $(\mathrm{G} \times \mathrm{E})$ in producing superior yield in Iwollo over Marketer, Super-marketer and Ashley.

\section{Conclusion}

The results obtained from the study showed that Poinsett-76 significantly performed better than Ashley, Marketer and Super-marketer. Pointsett-76 showed great adaptability to the climatic conditions of Iwollo. Based on the findings, Pointsett-76 could be recommended to farmers for improved cucumber production in Iwollo, South-Eastern Nigeria.

\section{Conflict of interest statement}

Authors declare that they have no conflict of interest.

\section{References}

Akinfosoye, J. A., Olafolaji, A. O., Tairu, F. M., Adenowola, R. A., 1997. Effect of Different Phosphorus levels on the yield of four varieties of rained cucumber (Cucumis sativa
L.). Proc. $15^{\text {th }}$ HORTSON Conf. 1, 65-66.

Breda, N. J., 2003. Ground based measurement of leaf area index: A review of methods, instruments and current controversies. J. Exp. Bot. 54(392), 2403-2417.

Clark, R.B., Zeto, S.K., Baligar, V.C., Ritchey, K. D., 1997. Growth traits and mineral concentrations of maize hybrids grown on unlimed and limed acid soil. J. Plant Nutr. 20(12), 1773-1795.

Cobeil, G., Gosselin, A., 1990. Influence of pruning and season on productivity of cucumber plants grown in a sequence cropping system. Sci. Hortic. 41(3), 189-200.

Costa, J. G., Campos, D. A. J. S., 1990. Maize cultivars recommended for the state of Acre. Counica de Tecino unidade de'Exeecuo de Numbito Estand. Field Crop Abstract. 44 (2), 4.

Duke, J., 1997. The Green Pharmacy. St. Martins Press, New York.

Eifediyi, E. K., Remison, S. U., 2010. Growth and yield of cucumber (Cucumis sativum L.) as influenced by farm yard manure and inorganic fertilizer. J. Plant Breed. Crop Sci. 2(7), 216-220.

Ekwu, L.G., Utobo, E.B., Onyesola, C. A., 2007. Vegetative and yield response of cucumber to staking and Nitrogen fertilizer application. J. Appl. Sci. 19(4), 7509-7519.

Enujeke, E.C., 2013a. Growth and yield responses of cucumber to five different rates of poultry manure in Asaba area of Delta state, Nigeria. Int. Res. J. Agric. Sci. Soil Sci. 3(11), 369-375.

Enujeke, E.C., 2013b. An assessment of some growth and yield indices of six varieties of watermelon (Citrullus lanatus Thumb) in Asaba area of Delta State, Nigeria. Int. Res. J. Agric. Sci. Soil Sci. 3(11), 376-382.

Enujeke, E. C., 2013c. Effects of variety and spacing on growth charactersof hybrid maize. Asian J. Agric. Rural Develop. 3(5), 296-310.

FAO, 2006. Cucumber Production in Pakistan. http:// www.faostat.fao.org

FMANR-Federal Ministry of Agricultural and Natural Resources, 1996. Soil Fertility Investigation (in 5 volumes). Fertility Ratings. Produced by the Federal Ministry of Agriculture, Lagos, Nigeria.

Garcia-Closes, R., Berenguer, A., Sanchez, M.J., 2004. Dietary sources of vitamins $\mathrm{C}$, vitamins $\mathrm{E}$ and specific cartenoids in Spain. British J. Nutr. 91, 1005-1011.

Gardner, F. P., Alle, V., McCloud, D. E., 1990. Yield characteristics of ancient roses of maize compared to modern hybrid. Agron. J. 82(5), 864-868.

GenStat Release 10.3DE, 2011. Discovery Edition 4 VSN International Ltd. Rothamsted Experimental Station, Howel, Hempstead, UK.

Hamid, A., Bloch, J.D., Naeemullah, K., 2002. Performance studies on six cucumber genotypes under local conditions of Swat. Int. J. Agric. Biol. 4, 491-492.

Ibrahim, K, Amans, A., Abubakar, I. U., 2000. Growth indices and yield of tomato (Lycopesicon esculentum Karest) varieties as influenced by crop spacing at Samaru. Proc. $18^{\text {th }}$ HORTSON Conf. 1, 40-47. 
Iken, J. E., Anusa, A., 2004. Maize Research and Production in Nigeria. Afr. J. Biotechnol. 3(6), 302-307.

Majanbu, I. S., Ogunlella, V.B., Ahmed, M.K., 1996. Responses of two Okro (Abelmoschus esculentus (L.) Moench.) varieties to fertilizer growth and nutrient concentration as influenced by nitrogen and phosphorus applications. Fertilizer Res. 8(3), 297-306.

Manyvong, V., 1997. Cucumber varietal trial. ARC/AVRDC Training workshop, Thailand.

Maplandia, 2015. Iwollo-Oye. Retrieved on September 12, 2016 from: http://www.maplandia.com/nigeria/enugu/ ezeagu/iwollo-oye.

Maqsood, A., Abdul, H., Zarqa, A., 2004. Growth and yield performance of six cucumber (Cucumis sativus L.) cultivars under agro-climatic condition of Rawalakot, Azad Jammu and Kashmir. Int. J. Agric. Biol. 6(2), 396399.

Mingbao, L., 1991. Cucumber Varietal Trial. ARC/AVRDC Training Bangkok Thailand.

Obi, I.U., 2002. Statistical Methods of Detecting Differences Between Treatment Means and Research Methodology Issues in Laboratory and Field Experiments. Ap. Express Publication Company, Nsukka, Nigeria. 117p.

Odeleye, F. O., Odeyeye, M. O., 2001. Evaluation of morphological and agronomic characteristics of two exotic and two adapted varieties of cucumber (Cucumis sativa L.) in South West Nigeria. Proc. $19^{\text {th }}$ Annual Conf. HORTSON. 1, 140-145.

Ojeifo, I. M., Nzekwe, U., Akpovwovwo, N. F., 2008. Growth and yield of five varieties of cucumber (Cucumis sativus) in southern Nigeria. J. Agric. For. Social Sci. 6(2), 234238.

Okonmah, L. U., 2011. Effects of different types of staking and their cost effectiveness on the growth, yield and yield components of cucumber (Cucumis sativus L). Int. J. Agric. Sci. 1(5), 290-295.

Phu, N.T., 1997. Nitrogen and potassium effect on cucumber yield. AVI 1996 report, ARC/AVRDC Training Thailand.

Ray, J. D., Sinclair, T. R., 1997. Stomatal closure of maize hybrid in response to drying soil. Crop Sci. 37(30), 803807.
Renner, S. S., Schaefer, H., Kocyan, A., 2007. Phylogenetics of Cucumis (Cucurbitaceae): Cucumber (C. sativus) belongs in an Asia/Australian clade far from melon $(C$. melo). BMC Evol. Biol. 7, 58.

Resende, G.M.de., 1999. Yield of pickling cucumber in the north of Minars Gerais State, Brazil. Hort. Brasil. 17, $57-$ 60.

Sajjan, A.S., Shekhargounda, M., Badanur, I., 2002. Influence of data of sowing, spacing and levels of nitrogen on yield attributes and seed yield of Okro. J. Agric. Sci. 15(2), 267274.

Sharma, A.K., Goel, K. R., Kumar, R., 2000. Performance of cucumber cultivar under protected cultivation. Himachal J. Agric. Res. 26, 175-177.

Shetty, N.V., Wehner, T. C., 1998. Evaluation of oriental trellis cucumbers for production in North Carolina. Hort. Sci. 33(5), 891-896.

Simon, P. W., 1992. Genetic improvement of vegetable carotene content. In: Biotechnology and Nutrition. (Eds.: Bills, D.D., Kung, S.D.). Proc. $3^{\text {rd }}$ Intl. Symp., Butterworth -Heinemann, Boston. pp.291-300.

Stolk, J.H., Cools, M. H., 1980. Cucumber varieties for the hot house crop. Groenten en Fruit. 36, 34-35 [Hort. Abst., 51 (6): 5448; 1981].

Tatlioglu, T., 1993. Cucucmber: Cucumis sativus L. In: Genetic Improvement of Vegetable Crops (Kallo, G., Bergh, B. O.). Pergamon Press Ltd., Tarrytown, New York.

Vimala, P, Ting, C.C., Salbiah, H., Ibrahim, B., Ismail, L., 1999. Biomass production and nutrient yields of four green manures and their effects on the yield of cucumber. J. Trop. Agric. Food Sci. 27, 47-55.

Wang, Y.H., Joobeur. T., Dean, R. A., Staub, J.E., 2007. Cucurbit genome mapping and molecular breeding in plants. Vegeta (5).

Wehner, T.C., Maynard, D. N., 2003. Cucumbers, melons and other cucurbits. In: Encyclopedia of Food and Culture (Eds.: Katz, S. H.). Scribner and Sons, New York.

Zaki, N.M., El-Gazar, M.M., El-Din, K.M.G., Ahmed, M.A., 1999. Partition and migration of photosynthates in some maize hybrids. Egypt J. Appl. Sci. 14(6), 117-139.

\section{How to cite this article:}

Adinde, J. O., Anieke, U. J., Uche, O. J., Aniakor, A. C., Isani, L. C., Nwagboso, A. A., 2016. Assessment of performance of four cucumber (Cucumis sativus L.) cultivars in Iwollo, South-Eastern Nigeria. Int. J. Curr. Res. Biosci. Plant Biol. 3(10), 136-143. doi: http://dx.doi.org/10.20546/ijcrbp.2016.310.016 